\title{
Large skeletal chromites in the Vourinos ophiolite, Greece
}

\author{
Flemming G. Christiansen and Niels $\emptyset$. Olesen
}

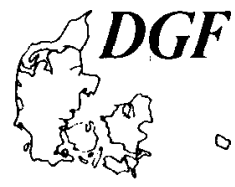

\begin{abstract}
Christiansen, F. G. \& Olesen, N. Ø.: Large skeletal chromites in the Vourinos ophiolite, Greece. Bull. geol. Soc. Denmark, Vol. 38, pp. 33-42, Copenhagen, April 25th, 1990.

https://doi.org/10.37570/bgsd-1990-38-03

Exceptionally large skeletal chromites, up to several $\mathrm{cm}$ across, from harzburgite veins in the Vourinos ophiolite, Greece have been described in detail using microstructural and fabric methods of silicate minerals combined with S. E. M. studies of chromite. Inferred from olivine fabric data, the harzburgite veins with the skeletal chromites have suffered only minor deformation (both in the ductile and brittle regime) compared to the highly deformed dunite host rock. The S. E. M. observations (electron channeling patterns) demonstrate (1) the large grain size of the chromite and (2) that the numerous grain facets are dominated by $\{111\}$ lattice orientations. Furthermore the chromite displays local plastic deformation and it is highly fractured and typically displays tilts/rotations $\sim 1^{\circ}$ of the lattice across the fractures.

The harzburgite veins formed during a late-tectonic stage of mantle flow. A metamorphic segregation model, where the skeletal growth of chromite was caused by super-saturation of $\mathrm{Cr}$ during diffusion, is the most likely mode of formation.
\end{abstract}

F. G. Christiansen \& N. Ø. Olesen, Geologisk Institut, Aarhus Universitet, C. F. Møllers Allé, DK-8000 Aarhus C, Denmark, January 26th, 1989.

\section{Introduction}

Chromite deposits, both of stratiform and ophiolitic types, are generally considered as the result of igneous processes. In an ophiolite consensus model, the chromite concentrations represent the early fractionation of melts rising beneath constructive plate margins (Menzies \& Allen 1974; Brown 1980; Augé \& Roberts 1982). The deposits are hosted by strongly deformed harzburgite of presumed residual mantle origin and recognition of relict igneous structures in the ore plays an important role in interpretation of ore genesis. The various described features include chromite net and chain structures, occluded silicates (Thayer 1969), ratio and phase layerings, and euhedral chromite grains in poikilitic pyroxenes (Augé \& Roberts 1982). Also chromite nodules with "hollow" dendritic cores (Greenbaum 1977), chromite dendrites between nodules ( $\mathrm{Pa}$ nayiotou, Michaelides \& Georgion 1986), and chromite orbicules (Leblanc, Cassard \& Juteau 1981), which are all typical for and restricted to ophiolitic deposits, are usually proposed to be igneous in origin.

A cautious approach to "magmatic-looking" features in the often highly deformed ore bodies has, however, been pointed out by Christiansen \& Roberts (1986) who demonstrated that microstructures resembling igneous crescumulates were formed by subsolidus growth during mantle flow. The implications for such a reinterpretation are strong, since - as a consequence - the exploration strategy is directed from primary magmatic deposits towards structurally controlled highly deformed ore bodies (e.g. Christiansen 1986a; Roberts, Rassios, Wright, Vacondios, Vrachatis, Grivas, Nesbitt, Neary, Moat \& Konstantopolou 1988).

The present paper describes some large, impressive, skeletal chromite grains in coarsegrained harzburgites from the Vourinos ophiolite, Greece. The interpretation of these features is also important for the understanding of ore genesis and deformation. A microstructural and fabric study of both olivine and orthopyroxene, combined with a detailed crystallographic study of the chromite employing the S. E. M. operated in electron back-scatter mode, suggests that the chromite formed during a late-tectonic stage of mantle flow, probably as a result of metamorphic segregation. 


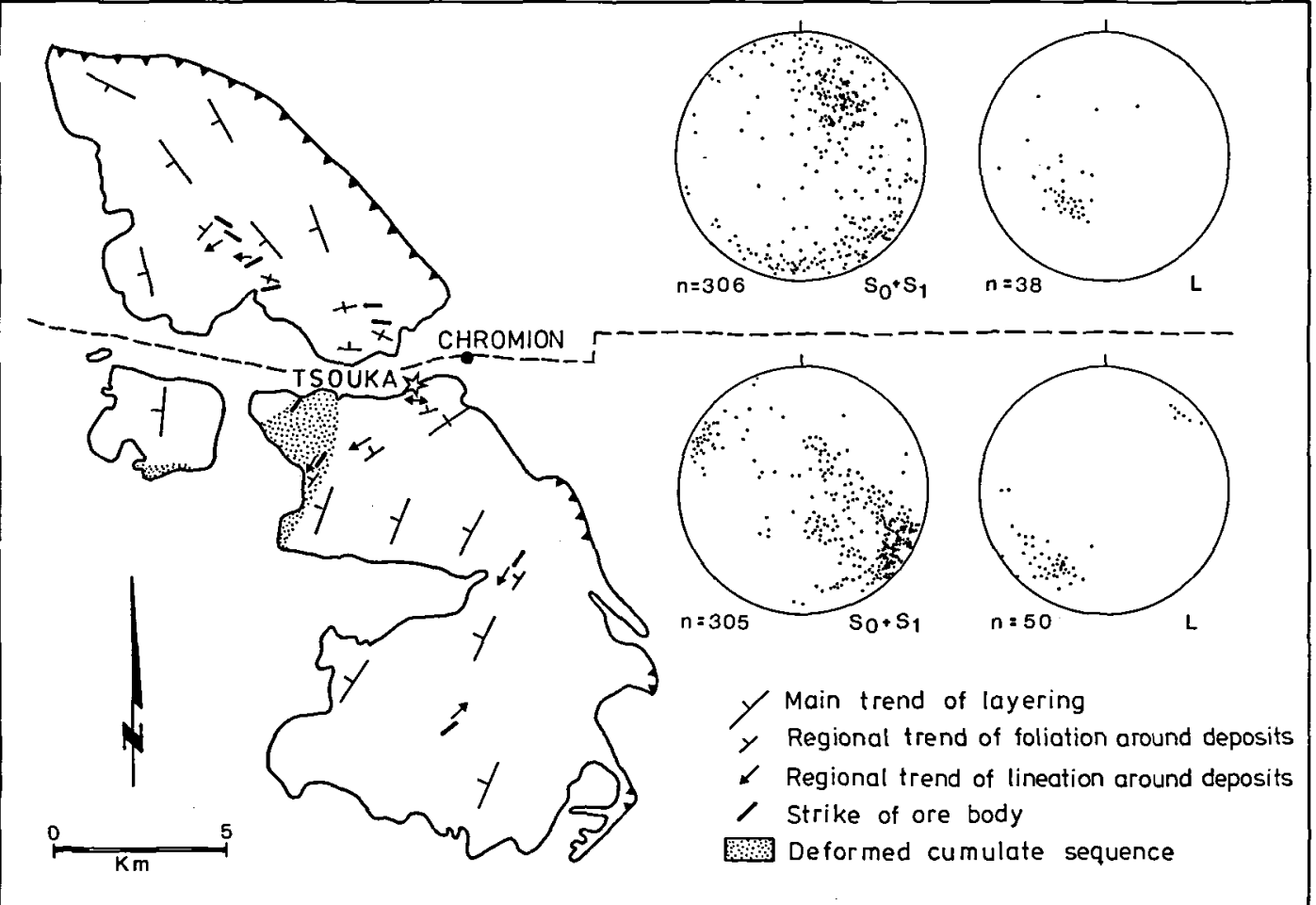

Fig. 1. Structure of the Vourinos ophiolite, which is situated approx. $100 \mathrm{~km}$ southwest of Thessaloniki. Lower hemisphere stereographic projections display measured mesoscale structures, modified after Christiansen (1986a). Main trend of layering is partly after Ross et al. (1980). The star indicates the study locality.

\section{Regional setting}

Euhedral chromite grains, up to several $\mathrm{mm}$ across, have previously been reported in a number of deposits in the Vourinos ophiolite (Burgath \& Weiser 1980; Christiansen 1982). The occurrence of $\mathrm{cm}$-sized skeletal crystals is restricted to a single locality situated close to the deposit "1.5 km SW of Chromion" (fig. 1) in a small river a few hundreds of metres upstream and west of the entrance to the old gallery of the mine.

The study locality is in the central part of the Vourinos complex, approximately $3 \mathrm{~km}$ east of possible, but deformed, basal cumulates in the Tsouka area (fig. 1). This part of the ophiolite is structurally homogeneous and dominated by interlayered harzburgite and dunite (Moores 1969; Ross, Mercier, Avé Lallemant, Carter \& Zimmerman 1980). The foliation, recognized by the preferred shape orientation of chromite and/or orthopyroxene, is well developed with a steep dip towards north. The associated lineation has a shallow westerly plunge. A slight clockwise rotation of both planar and linear structures is observed approaching the central, E-W trending, unexposed valley of the complex (fig. 1).

The large skeletal chromites occur in lenses or veins of coarse-grained harzburgite enclosed in well foliated dunite. Due to limited exposure individual harzburgite bodies can only be traced up to few metres along strike.

Two examples were sampled and studied in detail. One of these (sample FGC G 128) is a relatively little deformed harzburgite vein, approximately $10 \mathrm{~cm}$ across, which is concordant to the dunite foliation. Sample FGC G 129 is from the centre of an approximately $20 \mathrm{~cm}$ thick lens of "pegmatitic" harzburgite, in which a tendency for orthopyroxene and chromite to aggregate is clearly visible (fig. 2). The lens is also concordant to the dunite foliation but appears undeformed on outcrop scale. Both dunite and harzburgite are transected by numerous fracture zones, some of which are associated with serpentinization. 


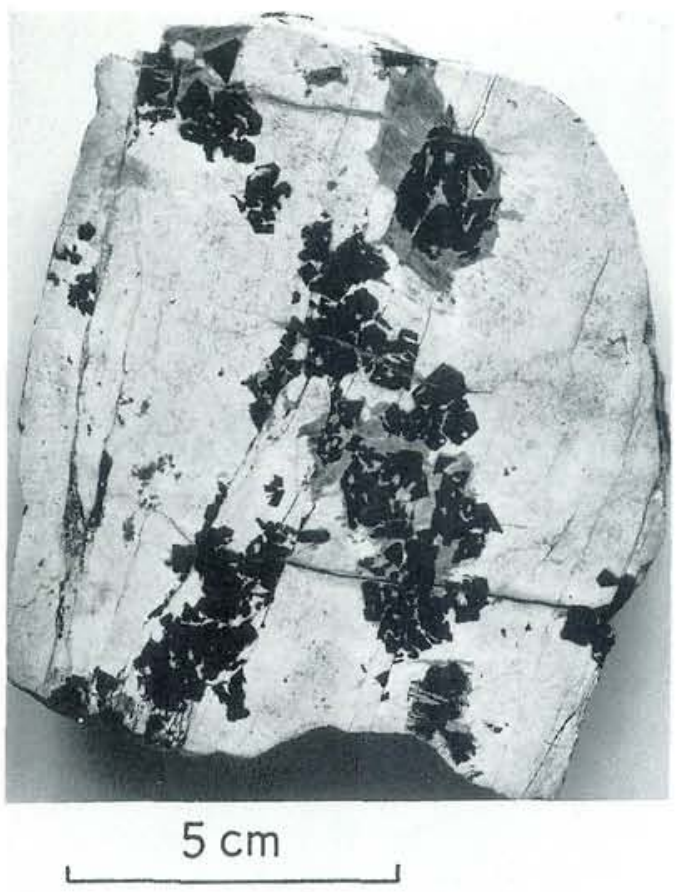

Fig. 2. Etched slab of sample FGC G $129(\sim 24 \mathrm{~h}$ in $10 \%$ cold $\mathrm{HCl}$ ). Chromite is black. orthopyroxene dark grey and olivine pale.

The composition of the chromites in both samples is similar to that of the chromite in the nearby mine (Augé pers. comm. 1984). This is in accordance with the constant composition of chromite throughout the Vourinos complex. Only smaller variations in the $\mathrm{Mg} / \mathrm{Fe}$ ratio were observed, which were interpreted to be caused by subsolidus reequilibration with surrounding olivine (Augé 1985).

\section{Silicate microstructure and fabric}

The two samples (FGC G 128: three thin sections, FGC G 129: six thin sections) were studied in the optical microscope by a combination of microstructural analysis and standard fabric measurements on a 5-axes Universal Stage (Emmons 1943; Möckel 1969). All recorded grains were identified and numbered on photographs, so that various microstructural domains could be compared.

Generally, both samples display a "coarse" microstructure (Harte 1977; Nicolas, Boudier \&
Boullier 1980) with a low degree of serpentinization $(<10 \%)$. Occasionally, thin cataclastic zones consisting mainly of angular, unaltered olivine grains, or later serpentine- or magnesite-filled veins, obscure identification of the structures considered in this study (e.g. fig. 3).

Straight to slightly curved (100) tilt-boundaries associated with some undulatory extinction are commonly observed in olivine, and this provides preliminary information on the crystallographic fabric (figs. 3, 5). Small recrystallized olivine grains occur in minor amounts along tilt- and grain-boundaries, especially near orthopyroxene.

Orthopyroxene displays a well developed cleavage (mainly $\{010\}$, to a lesser degree $\{110\}$ and $\{001\})$ and often contains exsolution lamellae. Undulatory extinction is common and kinkzones with a rotation of up to $10^{\circ}$ of the lattice are occasionally observed.

The three thin sections of sample FGC G 128 illustrate the weakly deformed harzburgite vein in a strongly deformed dunite host (fig. 3). A foliation and lineation in the dunite is reasonably well defined by single grains and grain-aggregates of chromite, whereas the olivine does not display any preferred shape orientation. Chromite, and especially the larger euhedral grains, is preferentially concentrated in the contact zone of the vein. The central part of the vein is dominated by a complex intergrowth between olivine and orthopyroxene (fig. 3).

The olivine bulk fabric of sample FGC G 128 is strong and asymmetric to the lineation and foliation (fig $4 \mathrm{a}$ ). $[100]_{01}$ forms a maximum $20^{\circ}-30^{\circ}$ to the lineation, whereas both $[010]_{01}$ and $[001]_{01}$ define a perpendicular girdle. This olivine fabric pattern is typical of mantle flow on the high temperature slip system $(0 \mathrm{kl})$ [100] (Carter \& Avé Lallemant 1970; Nicolas et al. 1973), and it has previously been reported from the Vourinos ophiolite (Jackson, Green \& Moores 1975; Ross et al. 1980; Christiansen 1986b).

The strength of olivine fabric seems to change from the dunite to the centre of the harzburgite vein, here exemplified by $[100]_{01}$ which is the most sensitive, since it forms a point maximum (fig. 4b). The dunite shows a very strong maximum (domain I), also the contact zone has a relatively strong fabric (domain II), whereas the centre of the vein has a poorer but still reasonably well defined fabric (domain III). 


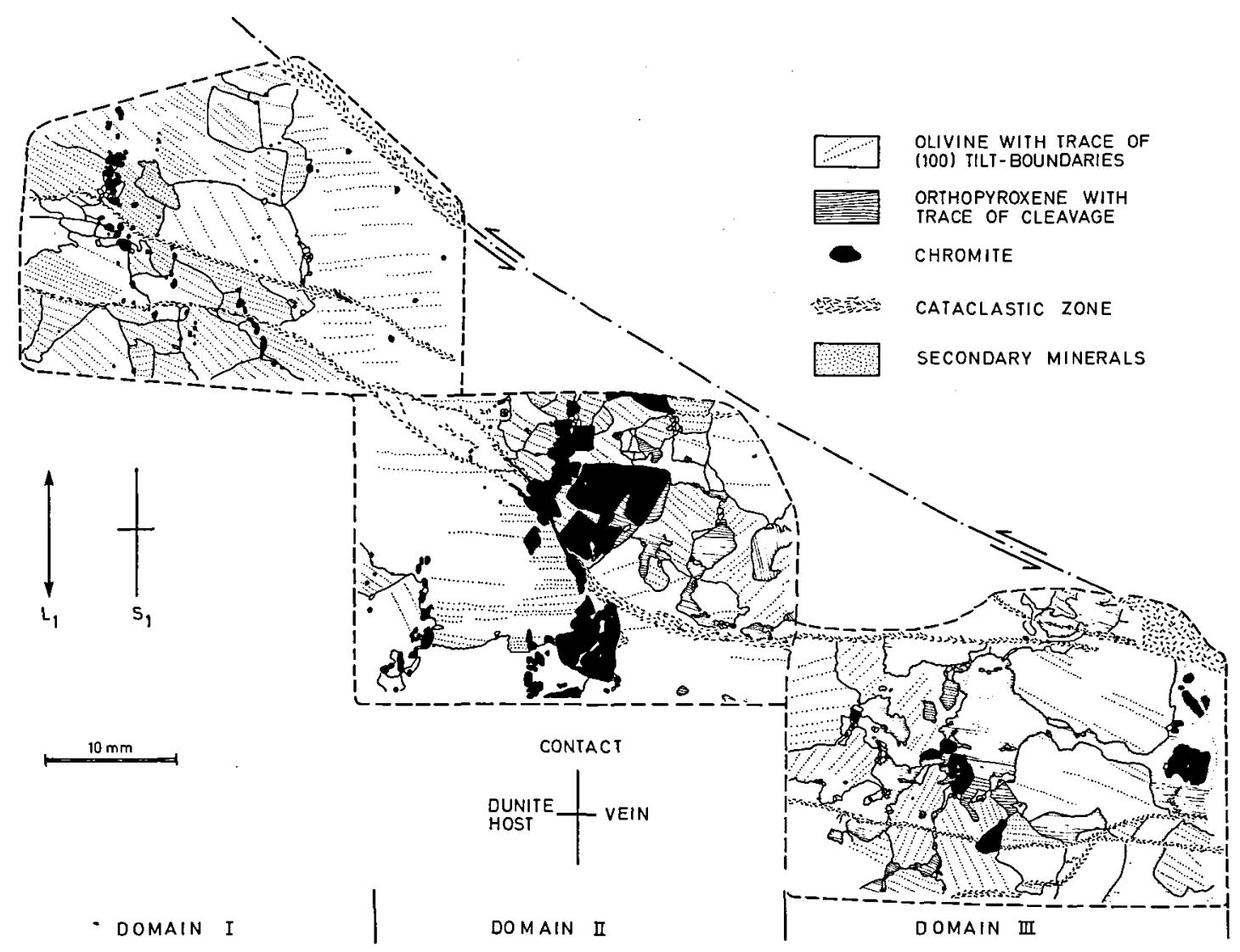

Fig. 3. Line drawing of three thin sections of sample FGC G 128 displays the relationship between dunite-harzburgite contact, foliation, microstructure and fabric.

The orthopyroxene in the centre of the vein has an almost constant orientation (less than $10^{\circ}$ rotation of the lattice) and it is probably part of a many $\mathrm{cm}$ large grain. The $[001]_{\text {opx }}$ direction is approximately normal to the vein. $[100]_{\mathrm{opx}}$ and $[010]_{\mathrm{opx}}$ are close to the plane of the contact, with the $[010]_{\mathrm{opx}}$ direction being approximately parallel to the regional lineation. This is well displayed in fig. 3 , where the $\{010\}$ cleavage outlines the constant orientation. This feature seems uncompatible with known deformational fabrics of orthopyroxenites, where $[100]_{o p x}$ is preferentially oriented at a high angle to the foliation plane (e.g. Etheridge 1975; Olesen 1986). The observed pattern is suggested to represent a growth fabric.

Only one of the six thin sections of sample FGC G 129 has been chosen to illustrate the microstructures of the central part of this impressive lens of harzburgite (fig 5a). The lens is char- acterized by large skeletal chromite grains enclosed in orthopyroxene (occasionally also in olivine). Both olivine and orthopyroxene are very coarse-grained and the U-stage measurements typically display only 1-5 different grain orientations (each with up to $20^{\circ}$ rotation of the lattice) within each thin section (fig. 5b).

Considering the combined orientation data from all six thin sections a number of irregular but well defined maxima appears. These maxima have no obvious relation to either the vein contact or to the regional foliation/lineation. The pattern suggests a complex intergrowth of several $\mathrm{cm}$ large olivine and orthopyroxene grains, resembling the exaggerated grain growth in highgrade quartzites (Wilson 1973) or the coarse interfingering grain-structure in high-temperature annealed ice (Wilson 1982). Deduced from the lustre in handspecimen, the typical size is estimated to be between 1 and $4 \mathrm{~cm}$. Although both 

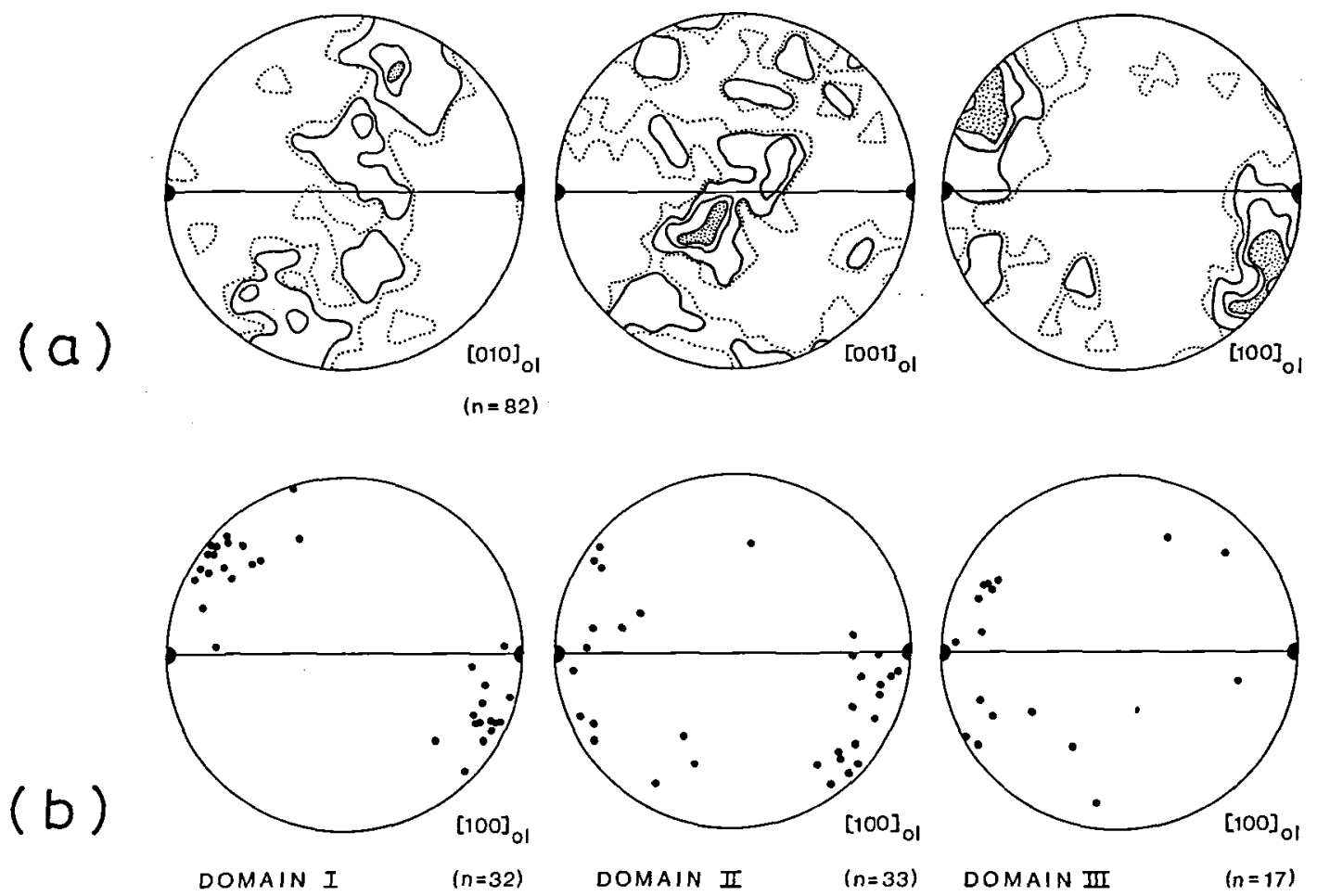

Fig. 4. Olivine fabric of sample FGC G 128. Foliation is east-west vertical, and lineation is east-west horizontal. a. Lower hemisphere equal area projection of $[010]_{01},[001]_{01}$, and $[100]_{01}$ of all 82 measured grains. Contours: $1 \%$ (dotted), $2 \%, 4 \%, 6 \%$ pr. $1 \%$ area. b. Scatter diagram showing the $[100]_{01}$ distribution in the three microstructural domains: I (dunite), II (contact zone), and III (vein).

minerals display high-temperature deformation features, it seems unlikely that the strain was high enough to develop a stable flow fabric but only modified the original orientation during minor rotation of the lattices.

\section{Chromite microstructure and orientation}

The chromites of the "pegmatitic" harzburgite lens (FGC G 129) typically display facetted habits, which suggest that they are up to $1.5 \mathrm{~cm}$ sized single crystals (figs. 2,5 ). In detail, silicate inclusions and embayments are plentiful, and preferred growth at edges/corners results in distinct skeletal to dendritic crystal habits.

One such grain was studied in detail with the SEM/ECP technique (Lloyd, Hall, Cockayne \& Jones 1981; Schmidt \& Olesen 1989).

The grain facets are dominated by $\{111\}$ lattice orientations (fig 6a). Micro-facetting is abundant (figs. 7a, 8a) with step-hights in the order of few tens of microns and down to a few microns, again with $\{111\}$ as the dominating lattice plane, supplemented with $\{100\}$ (fig. 8b). The variation in crystallographic orientation was "mapped" employing 32 points of orientation determination, distributed throughout the chromite grain (fig. 6). Two "orientation groups" are clearly distinguished; a major group of points with the electron beam axis near the [1-12] lattice direction, and a minor group (6 points) near the [101] direction. This indicates that the grain is actually composed of two crystals. Two points fall midway between the two groups, whereas the last point, form a tiny piece of chromite surrounded by silicates, falls off this pattern. The beam axis points of the major group spread over approximately $13^{\circ}$, whereas the minor group spreads over approximately $7^{\circ}$ (fig. $6 \mathrm{~b}$ ).

SEM/BSE observations demonstrate that the chromite grain is highly fractured (fig. 7a), a feature which is generally observed in polished sec- 
(a)

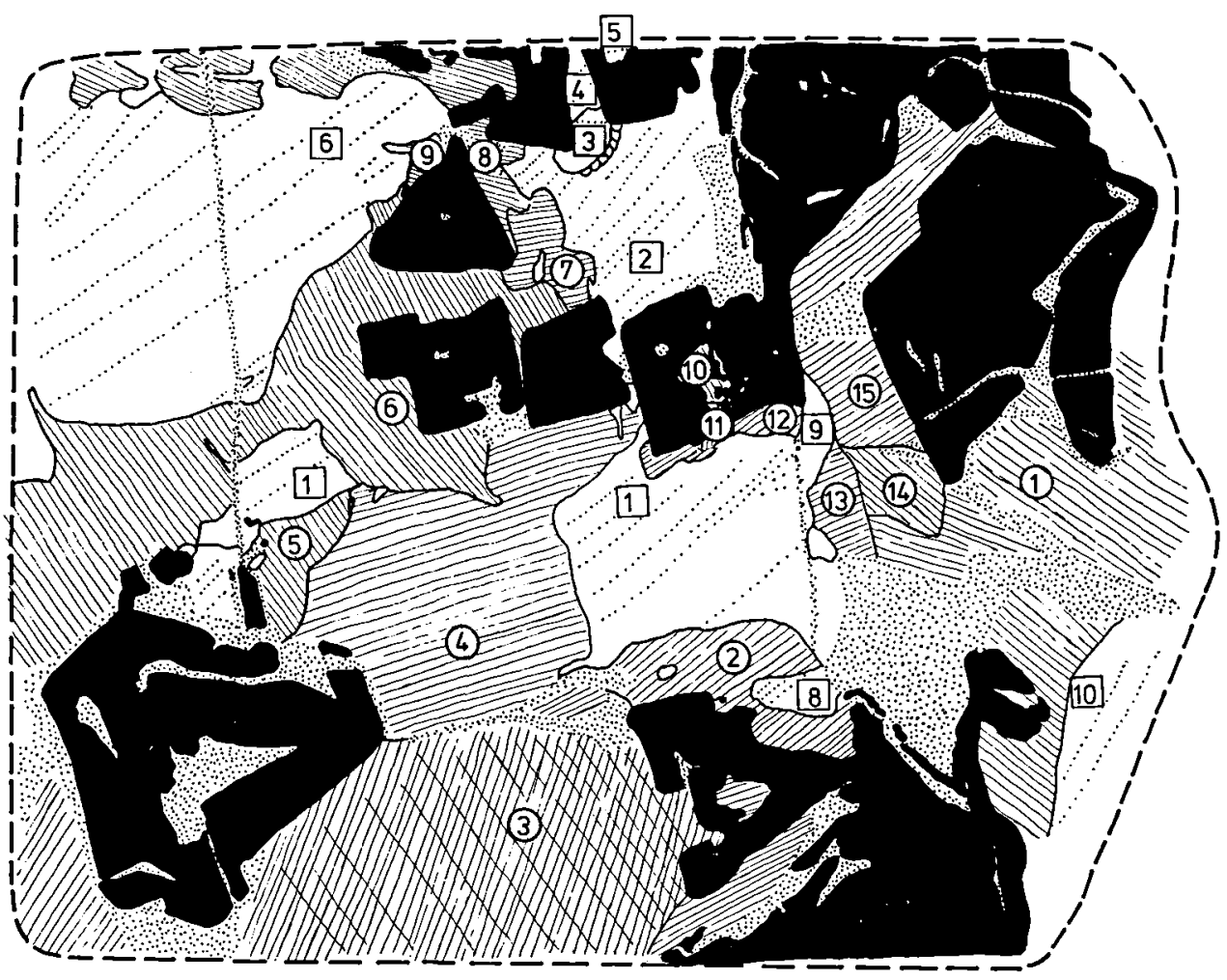

$10 \mathrm{~mm}$
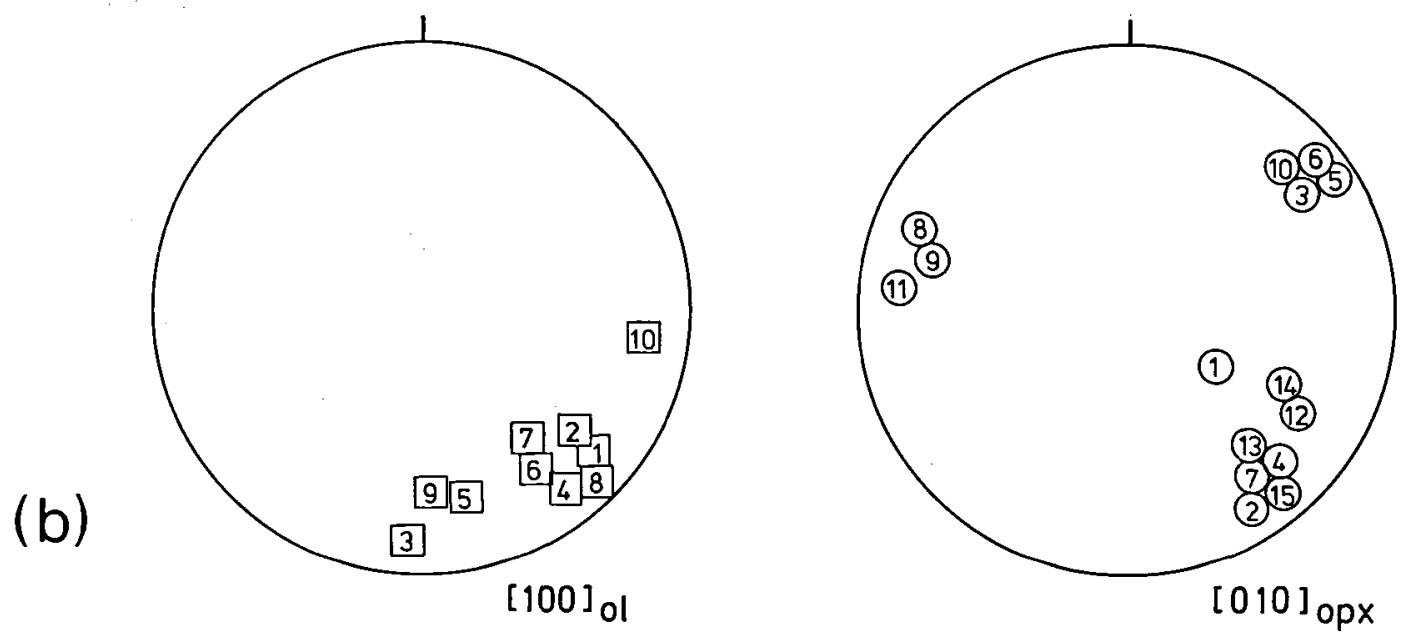

Fig. 5. a. Line drawing of one thin section of sample FGC G 129. Signatures as in fig. 3.

b. Lower hemisphere equal area projections of $[100]_{01}$ and $[010]_{\text {opx }}$. The measured grains are numbered and indicated on Fig. $5 \mathrm{a}$. The aggregation of orientations in the projections is taken to indicate an original coarse grain size, where each point-group represents one original grain. 


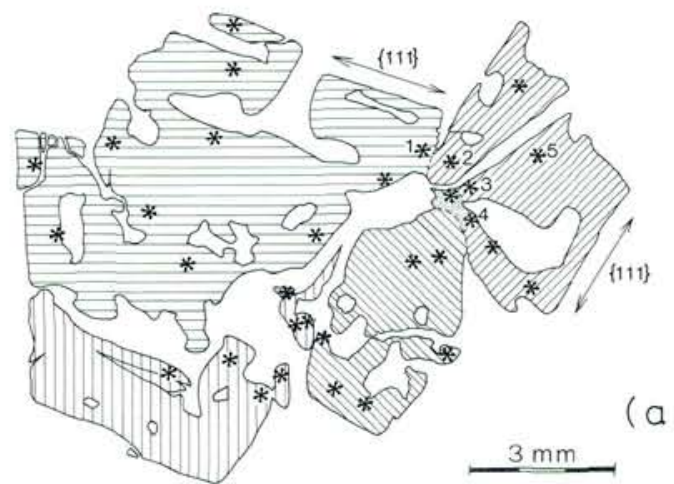

tions of other chromite grains. "Large-area ECP" demonstrates tilt/rotations in the order of $1^{\circ}$ across these brittle fractures (fig. 7b), which imply that at least some of the scatter of the beam axis point groups is due to shuffeling of grain fragments during a late stage of brittle deformation. Christiansen (1986b) observed similar features in other ophiolitic chromites.

Another fraction of the scatter is due to the presence of a few straight subgrain boundaries, which are observed to transsect parts of the grain (fig. 7a).

An irregular, fine-scale substructure is locally

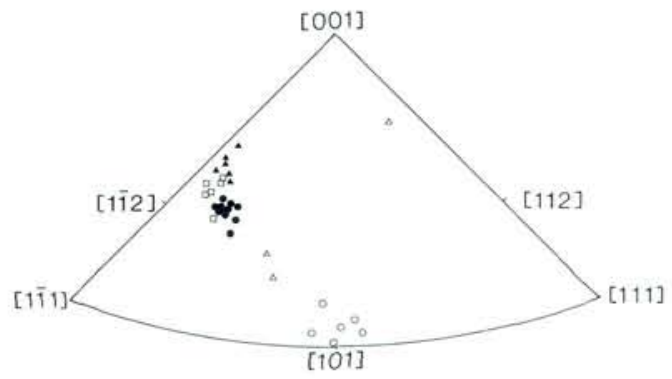
developed (fig. 9). It is similar to the substructure which Christiansen (1986b, fig. 3) observed in strongly deformed chromite, and it is interpreted
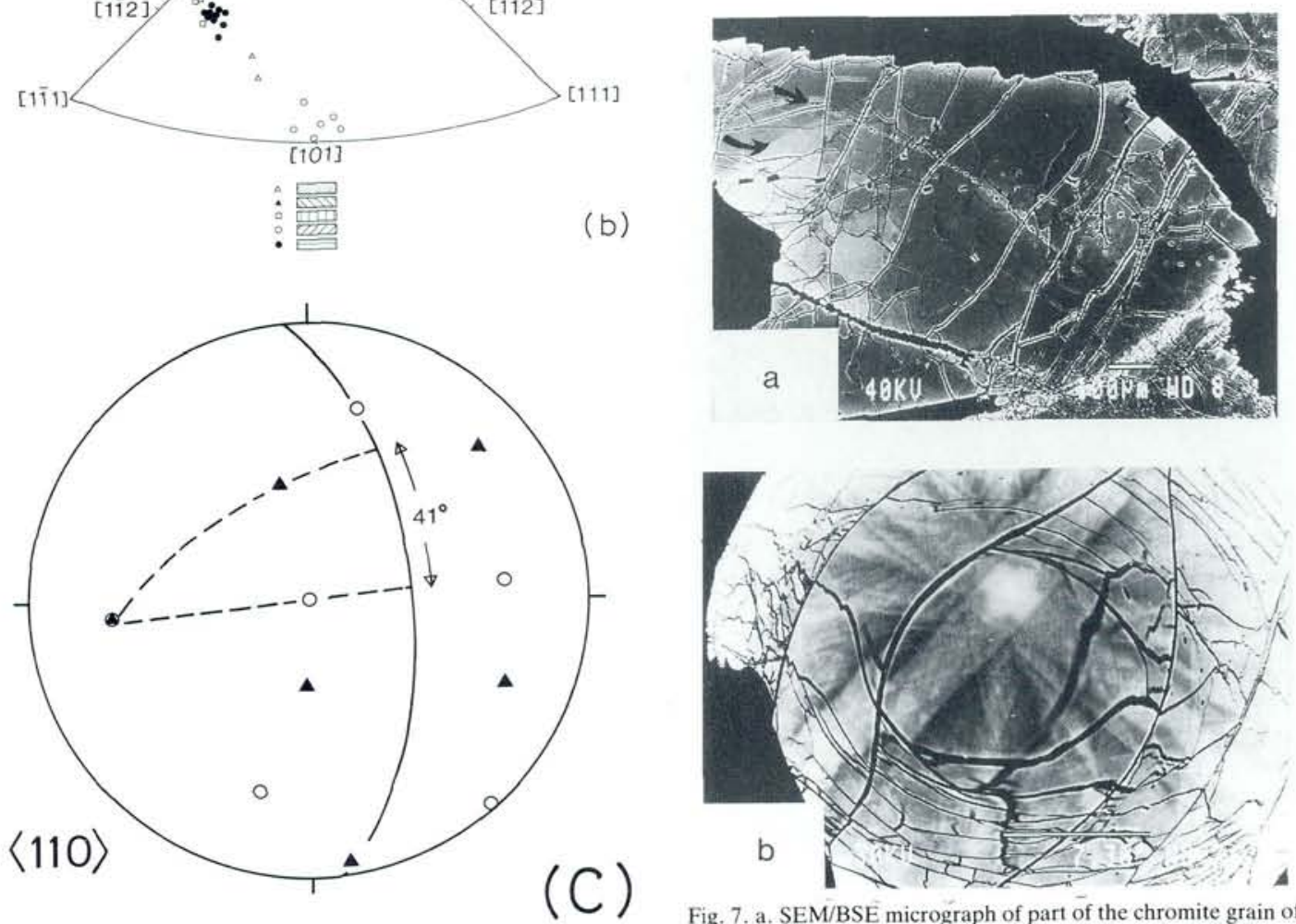

Fig. 7. a. SEM/BSE micrograph of part of the chromite grain of fig. $6 \mathrm{a}$. Beam axis point 2 is from the centre of the micrograph. Silicates are black, whereas chromite is in various shades of grey, due to variations in lattice orientation. Grain-boundaries and fractures are outlined by white fringes. A subgrain-boundary is indicated with curved arrow, and a possible healed crack with a straight arrow. Scale bar is $100 \mu \mathrm{m}$.

b. "Large-area ECP" of part of the chromite grain of fig 6a near beam axis point 5 . This instrumental setting results in marginal image distortion. Despite of this offsets of ECP-bands are clearly visible, which is due to lattice rotations during fracturing. Scale bar indicates a "rocking angle" of $7.3^{\circ}$. 


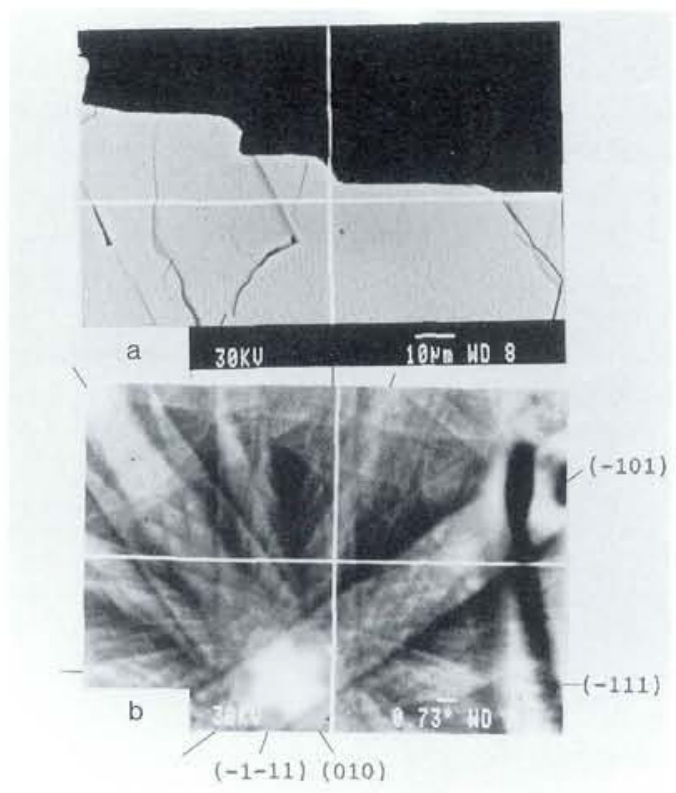

Fig. 8. a. SEM/BSE micrograph of part of the chromite grain of fig. $6 \mathrm{a}$ from near the beam axis point 3 . Silicates are black, and chromite is light-grey.

b. ECP-pattern from the chromite of fig 8a at centre of white cross. Illuminated area is approximately $10 \mu \mathrm{m}$ in diameter. The major ECP-bands are indexed and may be directly compared to the facets of fig. 8a.

to be due to plastic deformation by dislocation processes.

Trails of silicate (?) inclusions, commonly with "negative" crystal habits, transsect the grain (fig. $7 \mathrm{a}$ ). The size of individual inclusions ranges from a few to several tens of microns. Observation of fig. 7a suggests that a subgrain boundary is offset by approximately $10 \mu \mathrm{m}$ by such a trail of inclusions, which implies that the trails are healed cracks.

The two crystals forming the chromite grain of concern meet in grain boundaries, which are easily observed in the SEM/BSE mode, as highcontrast fringes along crack-like features (fig. 9). The complete crystallographic orientation of the and "major group" and "minor group" crystals was obtained from the ECP-patterns and is illustrated in fig. $6 \mathrm{c}$, based on two beam axis points, one from each crystal, near a mutual grain boundary. The two crystals display a symmetric orientation relationship, sharing a $<110>$ direction, with a rotation of $\sim 41^{\circ}$ around this common lattice direction (a spinel-twin-law relationship demands a rotation of $\sim 70^{\circ}$ around $<110>$ ).

\section{Discussion}

Skeletal growth morphologies are well known among minerals of the Spinel Series; in particular titanomagnetites and ilmenites display this habit in lava flows, where rapid cooling is an obvious physical parameter (Haggerty 1976; Gutmann 1977).

Surface nucleation is a necessary prerequisite for this type of interphase breakdown to take place, and surface nucleation is promoted by (1) under-cooling, (2) supersaturation, and (3) large crystal size (e.g. Wilcox 1977).

Two main modes of formation are possible in the proposed upper mantle setting, either a magmatic or a metamorphic segregation model. Dunite veins $(\mathrm{ol}+\mathrm{chr})$ and chromitite bodies $(\mathrm{chr}+$ ol $\pm \mathrm{cpx} \pm \mathrm{opx})$ are generally considered as the early fractionates af ascending magmas in the upper part of the mantle. This is also the most likely interpretation of the numerous chromite occurrences in the Vourinos ophiolite. However, all of the observed dunites and chromite occurrences seem to have suffered much stronger plastic deformation than the studied harzburgite veins (Christiansen 1986a).

It seems more likely that the studied veins formed considerably later in the geological history, probably just prior to emplacement but still under high P-T mantle conditions, in an off-axis position with limited magmatic activity. Although it is difficult to provide strong conclusive evidence in favour of any of the two models, a

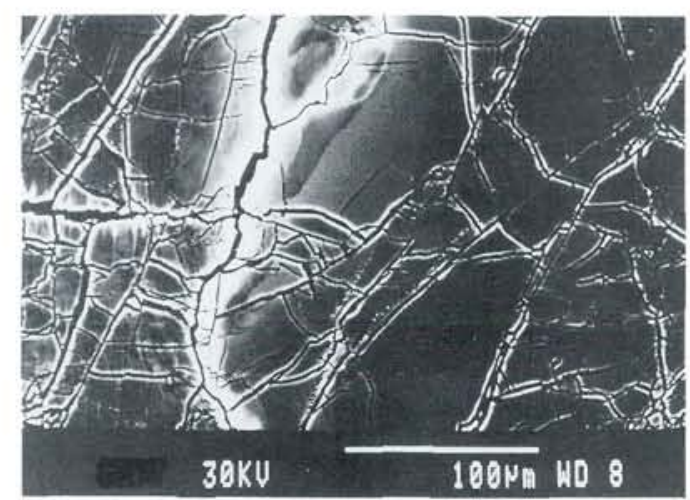

Fig. 9. SEM/BSE micrograph of part of the chromite grain of fig. $6 \mathrm{a}$ from near the beam axis point 4 . The white zone running from top to bottom of the micrograph is a grain-boundary. Substructures in left part of the micrograph are indicative of plastic deformation. 
metamorphic model is proposed here for a number of reasons:

(1) Rapid cooling of magma, and therefore large bulk undercooling, seems unlikely in the upper mantle environment.

(2) The veins clearly postdate the magmatic, but strongly deformed, dunites and chromites although they have also suffered minor deformation in both the ductile and brittle regime.

(3) The mineralogy and mineralogical composition reflects that of the enclosing and nearby observed dunite, harzburgite and chromitite.

(4) The veins are comparable to high-grade metamorphic segregation veins in other terrains, which commonly have a mineralogy and composition as their host rocks.

(5) Diffusion from the host rocks to the veins most likely created high $\mathrm{Cr}$ concentrations in the boundary zone between the growing silicates and the host dunites, which explains the skeletal growth of chromite as the result of supersaturation and nucleation difficulty.

Acknowledgements. - The present study was initiated as part of the Research and Development Programme "Structural and metamorphic processes that have contributed to or modified concentration of chromite" (Contracts MSM 120 DK and MPP 123 DK). The European Economic Communities are thanked for financial support.

The SEM work was supported by the Danish Natural Science Research Council (11-4715, 11-5333, 11-6543) and the lattice orientation determinations were performed with the application of the software package CHANNEL. N. H. Schmidt is acknowledged for making this available to us.

T. Augé and S. Roberts discussed many aspects of chromite geology in the field and elsewhere. J. S. Petersen kindly commented on a previous draft of the paper and L. Jans assisted with the technical preparation of the manuscript.

\section{Dansk sammendrag}

Tilstedeværelsen af relikte magmatiske strukturer er af stor betydning ved den genetiske tolkning - og senere prospektering - af kromit mineraliseringer i ofiolitiske kappe-bjergarter, i dette tilfælde fra Vourinos, Grækenland.

Usædvanligt store skeletale kromit-korn, som traditionelt ville være tolket som resultatet af magmatisk vækst, er beskrevet i stor detalje ved hjælp af mikrostrukturelle metoder.

Kromitten sidder i pegmatit-lignende harzburgit, som ud fra olivin fabric unders $\emptyset$ gelser tolkes som svagt deformeret, medens dunit værtsbjergarten er stærkt deformeret under kappebetingelser. Detail-studier af kromitten ved hjælp af scanning elektron mikroskopi demonstrerer den store kornstørrelse, \{111\} mikrofacetterede vakstflader, lokal plastisk deformation og talrige sprækker med mindre rotationer $\left(\sim 1^{\circ}\right)$ af krystalgitteret.
Det foreslås, at kromitten og harzburgit-årerne er dannet ved metamorf segregering $i$ den allerseneste fase af kappe-deformationen, formodentlig umiddelbart før opskydningen af ofiolitten, og at man således skal være påpasselig med en tolkning af magmatisk-udseende strukturer.

\section{References}

Augé, T. 1985: Platinum-group-mineral inclusions in ophiolitic chromitite from the Vourinos Complex, Greece. Can. Mineral., 23, 163-171.

Augé, T. \& Roberts, S. 1982: Petrology and geochemistry of some chromitiferous bodies within the Oman ophiolite. Ofioliti, 7, 133-154.

Brown, M. 1980: Textural and geochemical evidence for the origin of some chromite deposits in the Oman ophiolite. In: Panayiotou, A. (ed) Ophiolites. Geol. Surv. Cyprus, Nicosia, 714-721.

Burgath, K. P. \& Weiser, T. 1980: Primary features and genesis of Greek podiform chromite deposits. In: Panayiotou, A. (ed) Ophiolites. Geol. Surv. Cyprus, Nicosia, 675-690.

Carter, N. L. \& Avé Lallemant, H. G. 1970: High temperature flow of dunite and peridotite. Geol. Soc. Amer. Bull., 81, 2181-2202.

Christiansen, F. G. 1982: Field report: Structural analysis of chromite deposits in the Vourinos ophiolite, Greece. EEC Rep., 36 pp.

Christiansen, F. G. 1986a: Structural classification of ophiolitic chromite deposits. In: Gallagher, M. J. (ed) Metallogeny of basic and ultrabasic rocks. Institution of Min. and Metall., London, 279-289.

Christiansen, F. G. 1986b: Deformation of chromite: S. E. M. investigations. Tectonophysics, 121, 175-196.

Christiansen, F. G. \& Roberts, S. 1986: Formation of olivine pseudo-crescumulates by syntectonic axial planar growth during mantle deformation. Geol. Mag., 123, 73-79.

Emmons, R. C. 1943: The Universal Stage. Geol. Soc. Amer. Mem., 8, 205 pp.

Etheridge, M. A. 1975: Deformation and recrystallization of orthopytroxene from the Giles Complex, Central Australia. Tectonophysics, 25, 87-114.

Greenbaum, D. 1977: The chromitiferous rocks of the Troodos ophiolite complex, Cyprus. Econ. Geol., 72, 1175-1194.

Gutmann, J. T. 1977: Textures and genesis of phenocrysts and megacrysts in basaltic lavas from the Pinacate volcanic field. Am. J. Sci., 277, 833-861.

Haggerty, S. E. 1976: Opaque Mineral Oxides in Terrestial Igneous Rocks. In: Rumble, D. (ed) Oxide Minerals. Min. Soc. Am. Reviews in Mineral. 3, 101-300.

Harte, B. 1977: Rock nomenclature with particular reference to deformation and recrystallization textures in olivine-bearing xenoliths. J. Geol., 85, 279-288.

Jackson, E. D., Green, H. W. \& Moores, E. M. 1975: The Vourinos ophiolite, Greece: cyclic units of lineated cumulates overlying harzburgite tectonites. Geol. Soc. Amer. Bull., 86, 390-398.

Leblanc, M., Cassard, D. \& Juteau, T. 1981: Cristallisation et deformation des orbicules de chromite. Mineral. Deposita, $16,269-282$.

Lloyd, G. E., Hall, M. G., Cockayne, B. \& Jones, D. W. 1981: Selected area electron-channeling pattern from geological materials: specimen preparation, indexing and representation of patterns and application. Can. Mineral., 19, 505518.

Menzies, M. \& Allen, C. 1974: Plagioclase iherzolite - residual mantle relationships within two Eastern Mediterranean ophiolites. Contrib. Miner. Petrol., 45, 197-213. 
Moores, E. M. 1969: Petrology and structure of the Vourinos ophiolitic complex, Northern Greece. Geol. Soc. Amer. Spec. Pap., 118, 74pp.

Möckel, J. R. 1969: Structural petrology of the garnet-peridotite of Alpe Arami (Ticino, Switzerland). Leidse Geol. Meded., 42, 61-130.

Nicolas, A., Boudier, F. \& Bouchez, J. L. 1980: Interpretation of peridotite structures from ophiolitic and oceanic environments. Am. J. Sci., 280, 192-210.

Nicolas, A., Boudier, F. \& Boullier, A. M. 1973: Mechanisms of flow in naturally and experimentally deformed peridotites. Am. J. Sci., 272, 853-876.

Olesen, N. $\emptyset$. 1986: Three thrust sheets on Hornsnipa, Jotun Nappe Complex, West Norway. Nor. geol. Unders. Bull., $404,55-66$.

Panayiotou, A., Michaelides, A. E. \& Georgiou, E. 1986: The chromite deposits of the Troodos Ophiolite Complex, Cyprus. In: Petrascheck, W. (ed) Chromites, Unesco's IGCP-197 project Metallogeny of Ophiolites. Theophrastus Publications S. A., Athens, 161-198.

Roberts, S., Rassios, A., Wright, L., Vacondios, I., Vrachatis, G., Grivas, E., Nesbitt, R. W., Neary, C. R., Moat, T. \& Konstantopolou, L. 1988: Structural Controls on the Loca- tion and Form of the Vourinos Chromite Deposits. In: Boissonas, J. \& Omenetto, P. (eds) Mineral deposits within the European Community. Springer-Verlag, Berlin-Heidelberg, 249-266.

Ross, J. V., Mercier, J. C., Avé Lallemant, H. G., Carter, N. L. \& Zimmerman, J. 1980: The Vourinos ophiolite complex, Greece: the tectonite suite. Tectonophysics, 70 , 63-84.

Schmidt, N. H. \& Olesen, N. Ø. 1989: Computer-aided determination of crystal-lattice orientation from electron channeling patterns in the SEM. Can. Mineral., 27, 15-22.

Thayer, T. P. 1969: Gravity differentiation and magmatic emplacement of podiform chromite deposits. Econ. Geol. Monogr., 4, 132-146.

Wilcox, W. R. 1977: Morphological stability of a cube growing from solution without convection. J. Crystal Growth, 38, 73-81.

Wilson, C. J. L. 1973: The prograde microfabric in a deformed quartzite sequence, Mount Isa, Australia. Tectonophysics, $19,39-81$

Wilson, C. J. L. 1982: Texture and Grain Growth during the Annealing of Ice. Textures and Microstructures, 5, 19-31. 